\title{
Trade in minerals and human rights: towards responsible sourcing of minerals from conflict areas in Europe (Regulation (EU) 20I7/82I)
}

\author{
Nerea MAGallón Elósegui*
}

\begin{abstract}
Regulation 2017/82I laying down supply chain due diligence obligations for importers in the European Union establishes a common System of obligations that entail minimum standards of responsible sourcing hitherto unknown in Europe. It represents a positive trend in the strengthening of due diligence practices and respect for human rights by European companies when exercising cross-border activities. This paper provides an analysis of its application in order to highlight its possible strengths and weaknesses before it is finally implemented.
\end{abstract}

Keywords: European regulation - minerals - responsible sourcing - cross-border companies - obligations - due diligence

\section{(A) INTRODUCTION: DUE DILIGENCE AS A STARTING POINT}

Since the adoption of the UN Human Rights Council's Guiding Principles on Business and Human Rights (UNGPs), ' some mechanisms have been gradually implemented with the aim of protecting and respecting human rights, and remedying the adverse impacts and/or possible human rights abuses that business operations may cause in third countries.

Extrajudicial procedures are directed to protect and respect Human Rights (HR) and to remedy, prevent or mitigate any adverse effects on them. They are used as an alternative to judicial mechanisms for the reparation of damages, ${ }^{2}$ which are often fraught with procedural difficulties in the initial stages. As a result, due diligence has come to play such a leading role that it has become the main method used for this purpose. ${ }^{3}$ In this way, some progress has been

Article received on 2 I July 2020 , accepted ong October and published on ${ }_{3}$ December 2020

I 'Guiding Principles for Business and Human Rights: Implementing the United Nations "Protect, Respect and Remedy” Framework', UN Human Rights Council (A/HRC/RES/I7/3I), Human Rights Council Resolution I7/4 of i6 June 2oII, vid. J.E. Esteve, 'Los Principios rectores sobre las empresas transnacionales y los derechos humanos en el marco de las Naciones Unidas para proteger, respetar y remediar: ihacia una responsabilidad de las corporaciones o la complacencia institucional?' 27 Anuario español de Derecho Internacional, (20II).

${ }^{2} \quad$ Vid. M. Requejo Isidro, Violaciones graves de Derechos humanos y responsabilidad civil (The Global Law Collection. Thomson-Aranzadi, Cizur, 2oog); J.J, Álvarez Rubio and K. Yiannibas, (eds.), Human Rights in Business: removal of barriers to Access to Justice in the European Unión (Routledge, NY, 20I7).

3 Due diligence can be defined as '(...)an ongoing management process that a reasonable and prudent enterprise needs to undertake, in the light of its circumstances (including sector, operating context, size and similar factors) to meet its responsibility to respect human rights', as stated by the United Nations High 
made in terms of the duty of States to protect human rights and the responsibility of companies to respect them. This is been attained through a series of national and international sectoral measures, ${ }^{4}$ including Regulation (EU) $2017 / 82 \mathrm{I}$ of the European Parliament and of the Council of 17 May $2017,{ }^{5}$ with forms the core of this paper.

Regulation $2017 / 82$ laying down supply chain due diligence obligations for Union importers of tin, tantalum and tungsten, their ores, and gold originating from conflict-affected areas (hereinafter referred to as the Conflict Minerals Regulation) is aimed at addressing the challenge of ensuring that due diligence is implemented regarding conflict minerals, as set out in the second pillar of the Guiding Principles. ${ }^{6}$ Under the Conflict Minerals Regulation, prevention is encouraged in a particularly topical area by establishing a set of obligations directed at preventing EU trade of natural resources the extraction of which is likely to cause sustained violations of human rights.

This is not the first time that the European Union (EU) has adopted a Regulation in order to alleviate the negative consequences that the growing demand for a given product and its trade, together with the institutional and governance shortfalls of the producing countries, may have for the environment, for societies and for people whose way of life revolves around that product. ${ }^{7}$ A political initiative was also taken at that point, of which the EU was the main driving force, which was later strengthened by the $20{ }_{5}$ Paris Agreement. ${ }^{8}$ In this scenario, the fight against climate change has not only been seen as a necessity to achieve a cleaner world and sustainable development, ${ }^{9}$ but also as an opportunity for investment and innovation in the field of renewable energies, since it will bring growth to the markets for goods and services related to energy efficiency produced in the $\mathrm{EU}$.

The EU has set itself the target of reducing greenhouse gas emissions by $40 \%$ by $203^{\circ} .^{{ }^{\circ}}$ In

Commissioner for Human Rights in 'The corporate responsibility to respect human rights. An Interpretive Guide', United Nations, 2012.

4 Of relevance are the French law on the duty of vigilance of parent companies, the Dutch Child Labour Due Diligence Act and the Draft UN Treaty on Business and Human Rights.

5 OJ 19 May 20I7, $\mathrm{Liz}_{3} / \mathbf{I}$.

6 The Guiding Principles on Business and Human Rights contain $3^{\text {I }}$ principles organised around three pillars: the State duty to protect against human rights abuses by third parties, including business enterprises; the duty of business enterprises to respect human rights; and the need for more effective access to remedies for victims of human rights abuses.

7 Regulation (EU) No 995/2010 of the European Parliament and of The Council of 20 October 2oro, laying down the obligations of operators who place timber and timber products on the market, OJ, II November 2oro, $\mathrm{L}$ $295^{/ 23}$.

8 Paris Agreement adopted under the United Nations Framework Convention on Climate Change, see J. Juste Ruiz, 'El acuerdo de París sobre el cambio climático y los acuerdos no normativos o no jurídicos', in C. Martínez Capdevila (eds.) Principios y Justicia en el Derecho Internacional: libro homenaje al profesor A. Remiro Brotons, (Dykinson, 20I8), I73-18I.

$9 \quad$ Agenda 203 o on sustainable development.

Io $\operatorname{COM}\left(20{ }_{5}\right)$ 8I final, ${ }_{25}$ February 20I5, 'The Paris Protocol-A Blueprint for tackling global climate change beyond $2020^{\prime}$. 
the energy transition the priority of the 'Energy Union' is: 'to move away from an economy driven by fossil fuels'. "In this context, promoting 'clean mobility' is one of the main objectives, bearing in mind that transport accounts for at least a quarter of greenhouse gas emissions and is a major cause of pollution in cities. ${ }^{22}$ In line with these guidelines, there has recently been a significant increase in measures and incentives to encourage both the production and use of 'clean vehicles', namely electric and hybrid cars. ${ }^{13}$ In fact, increasing the production of socalled clean vehicles and boosting innovation in this field is seen as one of the great benefits for the Member States, for their industries and for their citizens; and it can position Europe as a leader in renewable energies.

Yet there is hardly any discussion on how clean vehicles move. The demand for the lithium batteries needed for their operation (similar to those used for computers and electronic devices) has increased proportionally to the demand for electric cars, in parallel to the growth in funding for technical innovations aimed at lowering their production costs to achieve greater competitiveness. Although it has barely been noticed, the ultimate driver of the momentum behind the progressively higher use of electric cars (and therefore, of the greenhouse gas reduction targets) has been their improved batteries. They provide increasingly greater autonomy at a lower cost, while also lowering pollution and reducing their negative effects on human rights.

Battery suppliers therefore have become key actors, and battery components are their main props. As batteries are made up of cobalt and lithium, among other elements, there has also been a significant increase in the demand for these minerals in recent years. However, cobalt is one of the most expensive minerals, due to its scarcity and to the difficulty in its extraction. Some $55 \%$ of the world's production is extracted from artisanal mines located in the Democratic Republic of the Congo (DRC). ${ }^{14}$ And the DRC, despite being one of the wealthiest countries in natural resources (gold, diamonds, copper, coltan, uranium and cobalt), is one of the poorest countries in the world. ${ }^{5}$ The profits from growing demand for the production of these raw materials do not seem to help the country break out of the cycle of poverty and political instability that has characterised it since its colonisation by king Leopold II of Belgium. On the contrary, it has been argued that there may be a 'resource 'curse', since the trade in these minerals (as with coltan, gold or diamonds) has plunged the country into a

\footnotetext{
I $\operatorname{COM(2015)~80~final,~}{ }_{5}$ February 2015, 'A Framework Strategy for a Resilient Energy Union with a ForwardLooking Climate Change Policy'.

I2 $\operatorname{COM(20I6)} 5^{\text {or final } 20}$ July 20I6, 'A European Strategy for Low-Emission Mobility’.

I3 Directive (EU) 20I9/ı6r of the European Parliament and of the Council of 20 June 2019 amending Directive 2009/33/EC on the promotion of clean and energy-efficient road transport vehicles, OJ I2 July 2019 , Lı88COM(20I7) 675 final, 8 November 2017 'Deliveringon low-emission mobility A European Union that protects the planet, empowers its consumers and defends its industry and workers'.

I/4 Date extracted from Cobalt Institute, last accessed on 12 October 2020.

I5 According to World Bank and UNHCR data.
} 
continuous struggle for control of mines, and has resulted in illegal exploitation ${ }^{16}$ and smuggling. This has caused not only to two civil wars, but also continuous armed conflicts in which sexual violence, forced displacements, looting, child labour, mutilations and all kind s of human rights violations are so common that they have become a part of the everyday lives of the country's population.

The Conflict Minerals Regulation set out a series of measures aimed at ensuring the responsible sourcing of minerals from so-called 'conflict-affected areas' (including the Democratic Republic of the Congo) in order to mitigate the negative effects of their trade. It includes a set of due diligence practices that companies sourcing minerals from these areas must comply with and enforce throughout the supply chain. This paper analyses: some similar measures that provide the legal background for the Conflict Minerals Regulation; the implementation of the Conflict Minerals Regulation and its functioning, with a view to explaining its strengths and weaknesses.

\section{(B) LEGAL BACKGROUND: OECD FOR RESPONSIBLE MINERAL SUPPLY CHAINS AND THE DODD-FRANK ACT}

(I) Due diligence in the Guiding Principles on Business and Human Rights

The Guiding Principles on Business and Human Rights (UNGPs) which were adopted by consensus by the UN Human Rights Council in 2oII, put into practice the UN 'Protect, Respect and Remedy' Framework. This is a comprehensive framework to integrate conflict mineral due diligence initiatives. Considering that risks to human rights result from the potential negative impact of companies' business operations, the Risk-Based Guiding Principles call for the prevention or mitigation of such negative impacts before damage occurs, and for the remediation of damage that has already occurred.

Principle 7 sets out the basic due diligence parameters for preventing the negative impacts that business activity can have on human rights, while Principles i 8 to 22 expand on these essential components. Human rights due diligence includes the identification and management of risks with the aim of preventing or mitigating their possible adverse effects and the establishment of a due diligence system that includes monitoring, evaluation and communication measures to ensure their successful progressive implementation.

The idea of anticipating the undesirable consequences of business activity in order to mitigate any potential risks to human rights risks underlies this principle. It promotes early action when an activity or relationship is in progress in order to prevent its negative effects from being carried along the entire supply chain. The earlier the due diligence process is

I6 Related to the mines in the Democratic Republic of the Congo see F. Triest, 'El sector minero en artesanal en el Congo oriental: condiciones de los emplazamientos y perspectivas', Alboan (ed.) Comisión de Justicia y Paz (Bilbao 2012). 
initiated in a business activity, the better the chances of mitigating its potential adverse effects. Taking the necessary measures to prevent the negative effects of the business activity and thus reduce the risks to human rights therefore becomes a basic pillar of due diligence. It has also been a key factor in the development of European Regulations on conflict minerals.

Compliance with the Guiding Principles requires that State Business and Human Rights Action Plans (NAPs) incorporate initiatives of positive law and public policies relating to, among other aspects: the articulation of due diligence processes; the inclusion of rights clauses in investment treaties; and the making available of effective redress mechanisms for the victims, both in and out of court. The adoption of many of these measures will require corresponding legislative reforms, which should be announced at the beginning of each NAP and have the necessary institutional support. However, due diligence has a heterogeneous presence and development in NAPs. In general, the differences lie in the way due diligence, or Principle 17, is approached in a more abstract manner: by promoting, guiding, inviting (Denmark, Finland, Chile, Colombia, Czech Republic, Ireland, Italy, Poland, Spain, Switzerland, Sweden and United Kingdom); or by proposing concrete measures to achieve the desired objectives and even deadlines (Belgium, France, Germany, Netherlands). The French NAP (like the Italian one) includes important initial diagnostic work and proposes the adoption of specific measures in the future. Whereas due diligence is not imposed by law in the Italian NAP, it undertakes to promote its adoption by reviewing existing legislation on public procurement. In the case of Norway, the NAP contains proposals linked to specific sectors.

The State must assist in the implementation of effective due diligence processes by providing the necessary tools for companies to comply with their due diligence duty. Nevertheless, most States have outlined a plan of intentions in their National Plans in which hardly any concrete tools are developed.

(2) The OECD Due Diligence Guidance for Responsible Supply Chains of Minerals from Conflict-Affected and High-Risk Areas

The 'OECD Due Diligence Guidance for Responsible Supply Chains of Minerals from ConflictAffected and High-Risk Areas' (hereinafter referred to as the OECD Conflict Minerals Guidance) was devised following the 'OECD Guidelines for Multinational Enterprises', included in the 'OECD Declaration on International Investment and Multilateral Enterprises'. ${ }^{17}$ The OECD Conflict Minerals Guidance is the first of a set of OECD Due Diligence Guidance documents developed for various sectors ${ }^{18}$ as non-binding recommendations. They

${ }^{17}$ For more on the OECD Guidelines, vid. P. T. Muchlinski, Multinational Enterprises deLaw, 2nd ed. (Oxford University Press, Oxford 2007), 658-7oo.

I8 The OECD has published sector-specific due diligence guidance documents for responsible supply chains in the agricultural, garment and footwear sectors, as well as good practice documents for the extractive and financial sectors: OCDE (2oI6 a.), OCDE (2or7a), OCDE (2oI7b), OCDE (2oI8), OCDE/FAO (2or7). On 3I May 2or8, 
were issued by OECD member state $^{19}$ governments and are addressed to multinational enterprises with the aim of encouraging responsible conduct in their business operations, regardless of the country in which they operate. The OECD Conflict Minerals Guidance was clearly used as a reference framework for the development of the EU Conflict Minerals Regulation. In fact, the Conflict Minerals Regulation was a response to the recommendation to promote compliance with the OECD Conflict Minerals Guidance and reflects the active involvement of the EU in the adoption of the Guidance document and its commitment to responsible sourcing from conflict areas.

The OECD Minerals Guidance was developed in 20II, ${ }^{20}$ and was a collaborative effort between governments, international organisations, industries and civil society. It provides a due diligence framework that should be used as a basis for companies to achieve responsible supply chain management of minerals from so-called conflict- or high-risk areas. Its objective is to help companies respect human rights and to engage in responsible supply practices that do not contribute to maintaining conflicts in these areas, by creating conditions conducive to agreements to be made with their suppliers that guarantee human rights. To this purpose, it provides an overarching risk-based due diligence framework for responsible supply chains of minerals from conflict and high-risk areas (Annex I); a model mineral supply chain policy that provides a set of principles (Annex II); and a series of suggested measures for risk mitigation and indicators for measuring improvement that upstream companies may consider with the possible support of downstream companies (Annex III). In addition, taking into account that specific due diligence requirements and processes differ depending on the mineral and the company's position in the supply chain, specific recommendations are established through Supplements for tin, tantalum, tungsten and gold that are adapted to the challenges associated with the supply chain structures of these particular minerals.

The effectiveness of the measures included in the Annexes of the OECD Conflict Minerals Guidance depend on a number of issues. Both the concept of 'risks' and the concept of 'supply chain' are particularly important, as they are used to establish the number of companies affected. 'The OECD Conflict Minerals Guidance defines 'risks' in relation to the potentially adverse impacts that the operations and activities of a company or its relationships with third parties may have. Adverse impacts may include harm to people (referred to as 'external impacts'), and reputational damage or legal liability for the company (referred to as 'internal

the OECD published the OECD Due Diligence Guidance for Responsible Business Conduct (OECD 2or8b).

19 Australia, Austria, Belgium, Canada, Chile, Czech Republic, Denmark, Estonia, Finland, F rance, Germany, Greece, Hungary, Iceland, Ireland, Israel, Italy, Japan, Korea, Luxembourg, Mexico, the Netherlands, New Zealand, Norway, Poland, Portugal, Slovak Republic, Slovenia, Spain, Sweden, Switzerland, Turkey, the United Kingdom and the United States of America.

${ }^{20}$ Approved by the OECD Investment Committee and the OECD Development Assistance Committee and endorsed by eleven member states of the International Conference of the Great Lakes Region (Angola, Burundi, Central African Republic, Republic of Congo, Democratic Republic of Congo, Kenya, Rwanda, Sudan, Tanzania, Uganda and Zambia). An additional Gold Supplement was adopted on 17 May 2012. 
impacts'). In view of the existing difficulty in proving liability for external damages in court, both types should be taken into account. In order to ensure that effective mechanisms are in place for human rights claims, it is crucial to argue that harm has been caused and, in the reverse, the degree of impact on competitiveness linked to internal impacts. The confluence between both types of damages can be found in the legal liability of companies for causing harm to people; and in terms of the difficulty in obtaining some form of reparation for the victims as a result of company liability, the key issue is the impact that this damage can have on their business reputation. Efforts to provide information and transparency are fundamental to ensure that consumers can play a role in establishing effective systems, since their behaviour indirectly affects companies' competitiveness.

The definition of 'supply chain' in the OECD Conflict Minerals Guidance refers to the process of bringing a raw mineral to the market. This process involves multiple actors who generally take part in the extraction, transport, handling, trading, processing, smelting, refining and alloying, manufacture and sale of the end product. The term 'supply chain' refers to 'the system of all the activities, organisations, actors, technology, information, resources and services involved in moving the mineral from the extraction site downstream to its incorporation in the final product for end consumers'. ${ }^{21}$ In this process, the companies involved are differentiated according to whether their participation in the supply chain is 'upstream' or 'downstream'. 'Upstream' companies include miners, local traders or exporters from the country of origin, international concentrate traders, mineral re-processors and smelters/refiners; and 'Downstream' companies include metal traders and exchanges, component manufacturers, product manufacturers, original equipment manufacturers (OEMs) and retailers. The OECD Conflict Minerals Guidance applies to all companies operating in a conflict-affected and high-risk area, or supplying or using tin, tantalum or tungsten, or their smelted derivates, from a conflict-affected and high-risk area.

Annex I is divided into five steps aimed at: (I) establishing strong business management systems, which include due diligence standards that are to be publicised, communicated, and guaranteed through a system of control and transparency applicable to all actors in the supply chain; (2) Identify and assess risks; (3) Design and implement a strategy to respond to identified risks (with the assistance of Annex II and Annex III); (4) Carry out independent thi rd-party audit of due diligence practices in supply chains; and (5) report on supply chain due diligence. Obviously, some flexibility is required in the application and implementation of due diligence, and the steps must be adapted to each company's own activities and its position in the supply chain. Taking the OECD Guidance and Gold Supplement as an example, it can be seen that a more specific distribution of obligations has been established for upstream companies than for downstream companies.

${ }^{21}$ Definition taken from p. 20 of the OECD Due Diligence Guidance for Responsible Supply Chains of Minerals from Conflict-Affected and High-Risk Areas. 
Finally, it should be noted that the OECD Conflict Minerals Guidance is voluntary and nonbinding. Therefore, there are no sanctions linked to non-compliance with its recommendations. The task of promoting and encouraging their correct application lies in the States, and it is the National Contact Points in each State that are responsible for promoting the effectiveness of the OECD Guidance and Guidelines. National Contact Points act as deliberative bodies and their role is promoting and facilitating out-of-court resolution of potential disputes related to non-compliance (with the recommendations set out in the OECD Conflict Minerals Guidance). ${ }^{22}$ Disputes are resolved through a procedure in which the National Contact Point mediates and attempts to reach consensus between the parties involved on the basis of compliance with the OECD Guidelines.

(3) Section 1502 of the Dodd-Frank Act.

A major financial reform was launched in the United States with the enactment of the Dodd Frank Financial Reform and Consumer Protection Act (the Dodd-Frank Act), ${ }^{23}$ signed into law by President Barack Obama on i July 2oro. It was aimed at restoring investor confidence in the integrity of the system and fostering its stability in the aftermath of the worst crisis since the Great Depression. As stated in the Preamble of the Dodd-Frank its main objectives were: to promote the financial stability of the United States by improving accountability and transparency in the financial system, to end the problems arising from financial institutions that are 'too big to fail', to protect the American taxpayer by ending bailouts and to protect consumers from abusive financial services practices.

Special attention should be paid to Section $5_{502}$ of the Dodd-Frank Act, which expressly refers to the exploitation and trade of minerals originating in the Republic of the Congo or an adjoining country. The objective of Section $5_{5} 02$ is to curb the serious human rights abuses related to the trade of certain minerals and reduce the capacity of armed groups that use the illegal trade in minerals to finance their activities, maintain control of mines and power, and foster conflict and political instability, and establish certain due diligence guidelines to be followed by potentially affected U.S. companies.

Section $5_{5}$ 2 of the Dodd-Frank Act set a pioneering national standard in integrating due diligence obligations for U.S. publicly traded companies that directly or indirectly (through their suppliers) use so-called conflict minerals in their manufactured products . ${ }^{24}$ And it is

${ }^{22}$ In Spain the Contact Point was created by Ministerial Order PRE/2r67/2014 of II November 2014, which established and regulated the composition and operation of the National Contact Point; vid. M. C. Márquez Carrasco and I. Vivas Teson, (coord.). La implementación de los principios rectores de las Naciones Unidas sobre empresas y Derechos humanos por la Unión Europea y sus Estados miembros (Thomson Reuters- Aranzadi and Spanish Ministry of Economy, Industry and Competitiveness, 2017).

23 Dodd-Frank Wall Street Reform and Consumer Protection Act, H.R. 4173,III Congress (20o9-20I0) of the United States of America.

24 M. C. Rodríguez de Ramírez, 'La polémica regulación de la Comisión de valores de Estados Unidos sobre minerales provenientes de zonas de conflicto en la cadena de suministros', Profesional y Empresarios (D\&G), XV, 
certainly a point of reference when analysing the European Conflict Minerals Regulation. US law has had a major influence on the process of drawing up the EU Regulation, especially throughout the discussions and negotiations that emphasised its unintended consequences on the countries of origin. The Dodd-Frank Act requires companies whose suppliers obtain minerals from a covered country ${ }^{25}$ to conduct a due diligence process to ascertain whether the purchase of such material could have a direct or indi rect link to the financing of armed groups. In order to report on the presence of conflict minerals in their products, companies within the scope of the Dodd-Frank Act must submit an annual report to the Security and Exchange Commission (SEC) by $3^{\mathrm{I}}$ May.

The first report from May 20I 4 was submitted to the SEC by more than I, ooo companies that may use conflict minerals. Global Witness and Amnesty International analysed roo of these reports and produced a document entitled 'Digging for transparency', which revealed the initial strengths of the Dodd-Frank Act and some of its shortfalls. ${ }^{26}$ Without going into an exhaustive analysis of the Act some conclusions of interest can be drawn that may be used as a starting point. Additional data from the Dodd-Frank Act will be used later when analysing the Conflict Minerals Regulation).

The first documents submitted to the SEC showed that most companies did not know if their products were linked to the activities of armed groups; and $4 \mathrm{~F} \%$ did not have a specific policy to identify risks in their supply chain. In fact, only $15 \%$ of the companies analysed appear to have contacted, or at least attempted to contact, the facilities that process the minerals into their products (foundries and refineries) and their research was limited to their direct supplier. Some $79 \%$ of the reports analysed did not comply with the general requirements established by the Dodd-Frank Act; however, the fact that the remaining $21 \%$ did in the first year of its application demonstrates that it is feasible to do so.

The absence of sanctions and independent external controls or audits is probably the weak point of the Act. During the first years after the implementation of the Dodd-Frank Act, the SEC established an obligation for the reports to be evaluated by external audits through the Small Entity Compliance Guide. ${ }^{27}$ But the obligation was repealed by a $20{ }_{4}$ Court of Appeals decision, which urged the SEC to issue a new guide in which a company should only have its due diligence activities audited on a voluntary basis if it freely chooses to describe its products as DRC conflict free. At the same time, the wording of the Act did not establish a system of sanctions for companies that submit incomplete or inaccurate reports, which reflected a common weakness that is usually inherent in due diligence mechanisms.

\footnotetext{
September 2or4.

${ }^{25}$ Democratic Republic of the Congo and its adjoining countries: Sudan, Uganda, Rwanda, Burundi, Tanzania, Zambia, Angola, Congo and Central African Republic.

${ }_{26}$ Global Witness and Amnesty International: Digging for transparency, How companies are only scratching the Surface of conflict minerals reporting'.

27 For more information see Small Entity Compliance Guide.
} 
Despite the initial hurdles, this is a type of report that had not previously been required of U.S. companies or their business operations in high-risk countries. This has placed the United States at the forefront of the efforts to ensure that companies obtain or market natural resources responsibly, guaranteeing respect for human rights. It is worth noting its innovative character and its encouragement for American companies to move towards responsible minerals sourcing beyond their borders. It has also served both as an incentive for the drawing up of the EU Conflict Minerals Regulation and as a model during the process.

\section{(C) THE EU CONFLICT MINERALS REGULATION}

(I) EU Conflict Minerals Regulation: a first step towards responsible minerals sourcing.

At the supranational level, the EU Conflict Minerals Regulation was adopted on 17 May 2017 in the wake of the Guiding Principles in Business and Human Rights and the OECD Conflict Minerals Guidance. Its objective was to establish proper due diligence in the supply chain through a 'proactive' and 'reactive' process. This required European economic operators to monitor and manage the sale and purchase of certain minerals in order to ensure that their activities would not contribute to perpetuating conflicts or negative effects resulting from their trade. ${ }^{28}$

The Conflict Minerals Regulation was adopted on the initiative of the European Parliament. It had the support of civil society, which on four separate occasions ${ }^{29}$ called on the EU to follow in the footsteps of Section $5^{02}$ of the Dodd-Frank Act. The Conflict Minerals Regulation was passed as a non-binding instrument, which after an intense debate took the form of recommendations. Therefore, the duty to verify and sanction the extent to which it is complied with was left to States, as established in Article I6.

The negotiations before the adoption of the Regulation reflected the existence of two approaches that marked the long debate and were reflected in the text that was finally adopted. On the one hand, the Commission's initial proposal, influenced by the antilegislation coalition, established a voluntary certification system for only a small part of the supply chain. This position was built on the desire to avoid the unintended consequences that the implementation of the Dodd-Frank Act had had on the Democratic Republic of the Congo and on minerals trade. It sought to end the de facto embargo on conflict minerals and the

${ }^{28}$ P. Diago Diago, 'El control del comercio internacional de los minerales en conflicto: el Reglamento (UE) $2017 / 82$ I por el que se establecen obligaciones en materia de diligencia debida en la cadena de suministro de estaño, tantalio, y wolframio y sus minerales y oro', 9099 Diario La ley, (2017); O. Martin-Ortega, 'Europa se enfrenta (por fin) al resto de los minerales conflictivos: el Reglamento $2017 / 82$ ', 45 Revista General de Derecho europeo, (2018), 276-298 and 'Human rights due diligence for corporations: from voluntary standards to hard law at least?', $3^{2}$ Netherlands Quarterly of Human rights (2014) I-31.

29 Resolutions of 7 October 20Io, 8 March 20II, 5 July 20 II and 26 February 20 \%4. 
unintended consequences linked to the stigmatisation of the territories listed in the US law. ${ }^{\circ}$

On the contrary, the pro-regulation coalition advocated a mandatory rule for both the importers of raw materials and for products containing the minerals considered to be conflict minerals. This position describes the de facto embargo as a necessary and temporary evil that has helped to reduce the income of armed groups and to provide greater security for mining territories. The unintended consequences of the rule were only effective in the short term and yet guaranteed long-term results. In the political process, the Parliament ended up representing this position and, although it is true that in the Parliament's Committees both positions were represented, on 20 May $20{ }_{5}$, it voted in favour of far-reaching amendments to the Commission's Proposal. During the process, there had been intense mobilisation in Europe calling for strong regulations, which undoubtedly influenced Parliamentarians. According to this position, as had been reflected in the first years of implementation of the Dodd Frank Act, the voluntary system could be ineffective. Most companies do not check suppliers and do not publish the necessary information on their due diligence practices, even if they are obliged to do so.

After the Parliament's vote, the Council of Ministers reached an ambiguous compromise that enabled the start of the trialogue of the European institutions in December 2or6. All positions aimed to reduce the unintended consequences of the US law and the key was whether to choose a voluntary or an obligatory system. The efforts of the Dutch government to reach consensus during its presidency culminated in a text that sought to strike a balance and included the idea that the volume of imports would determine whether the rule would be mandatory or not. It also included a system of thresholds that would exempt small and medium-sized enterprises from the excessive administrative burden of due diligence systems. As we will see, the text finally adopted represented a minimum agreement, which, after six years of negotiation, did not require compliance for the whole supply chain, but it was compulsory for direct importers of metals and minerals, which was a small, but important, step forward.

As in the case of its American counterpart, the Conflict Minerals Regulation established a supply chain due diligence system, the main purpose of which is to reduce opportunities for armed groups and security forces to benefit from trade in certain minerals, and thus to stop contributing to the negative consequences and continuing human rights violations associated with their trade (Article I). Although they agreed on the main objective, their approaches differed. Thus, the Minerals Regulations changed the focus from compliance with American law to a risk policy aimed at implementing a number of measures to increase transparency and certainty in the supply activities of the Union's importers, and of the smelters and refiners

$3^{\mathrm{O}}$ D-J., Koch and O. Burlyuk, 'Bounding policy learning? EU efforts to anticipate unintended consequences in conflict minerals legislation', I7 Journal of European Public Policy (2019), Pp. I-23. 
sourcing their minerals from conflict-affected or high-risk areas.

(2) Material scope of the Regulation: what are conflict minerals?

Today, high-technology components have been incorporated into our everyday lives at a rapidly increasing rate, as mobile phones, tablets and computers have become ubiquitous within daily tasks. The number of mobile phones in a family sometimes even exceeds the number of its members; they each have a tablet and a computer at an ever-younger age, and in many cases, households have a TV for each family member. The components that make up these technological devices include coltan, gold, tantalum and tin, each of them having a specific function within their structure. European countries cannot meet the growing demand for these raw materials and resort to those countries where the reserves of these minerals are located for their supply. For example, $70 \%$ and $80 \%$ of the world's reserves of tantalum (from which coltan is extracted) are found in the Democratic Republic of the Congo, especially in artisanal mines in the north of the country in Katanga, Maniema and Kivu. The geographical nature of this mountainous area and the lack of roads and electrical infrastructures pose logistical difficulties that render industrialisation ${ }^{31}$ virtually impossible.

Similarly, gold is used not only in jewellery but also in electronic instruments of all kinds; as well as cobalt, tungsten, copper and diamonds, ${ }^{32}$ minerals that are characterised by their scarcity and difficult extraction. In fact, the land of the Democratic Republic of Congo is also particularly rich in cobalt, from which the lithium batteries that move electric vehicles are made. As noted in the Introduction to this paper, these have become a solution to the harmful effects of greenhouse gas.

The Conflict Minerals Regulation, as Section ${ }_{5} 5^{02}$ of the Dodd-Frank Act, is intended to prevent the trade in minerals in areas considered politically unstable from being used to finance armed groups and forced labour, and to curtail opportunities for the violation of human rights corruption and money laundering. In order to establish the material scope of the Conflict Minerals Regulation, two aspects should be taken as a starting point: what type of minerals it covers, and which areas are considered to be conflict or high-risk areas. The combination of both will result in the definition of 'conflict minerals'.

Minerals falling within the material scope of the Conflict Minerals Regulation are the socalled ' 3 Ts and G'. ${ }^{33}$ These are minerals or metals which either contain or consist of tin,

$3^{\text {I }}$ See, F. Triest, 'El Sector minero artesanal en el Congo Oriental: condiciones de los emplazamientos y perspectivas', Alboan (ed.), Comisión de Justicia y Paz, (Bilbao, 2012).

$3^{2}$ In order to prevent the illegal trade in diamonds and its negative effects on human rights, a Certification Scheme for diamonds, called the Kimberley System, was established in 2oo2, P. Diago Diago, 'Los diamantes de conflicto y el comercio internacional: necesaria evolución del sistema PK', 8364, Diario la Ley, (2014) and 'El comercio internacional de diamantes: Sistema de certificación del Proceso Kimberley', in vol. I., no. I, Cuadernos de Derecho Transnacional (March 2009), 72-9I.

33 Tantalum, tungsen and tin + gold. 
tungsten, tantalum or gold and are within the minimum thresholds laid down in Annex I (Article 18 ). These must be reviewed and updated every three years from the application of the Regulation. This is a restrictive delimitation that leaves out minerals with similar characteristics such as cobalt and copper, among others, the demand for which has been increasing in recent years.

As in the case of the Dodd-FrankAct, the Conflict Minerals Regulation only includes certain types of minerals which, moreover, must be found in a predetermined minimum percentage. Therefore, the material scope of the Regulation is limited and restricted; however, it would have been more appropriate to have been defined more extensively by using common criteria based on the sudden increase in the demand of certain minerals, by their scarcity or by the difficulty in their extraction. This would have made it possible to include minerals such as cobalt, which has similar characteristics to those established in the Regulation, and to update the application of the Conflict Minerals Regulation according to the minerals affected, by linking their trade with potential human rights violations.

The OECD's Conflict Minerals Guidance provided a more consistent response, by permitting the potential extension of the mechanisms put in place to new minerals, in order to promote responsible sourcing. Its structure establishes some basic models that help companies to achieve their objective, but then complements them with specific Supplements for each mineral. This allows companies to adapt to the characteristics of the trade of that type of mineral and to better meet their needs, and Supplements can also be added as needed. As can be seen, the first version of the OECD's Conflict Mineral Guidance included Supplements on Tin, Tantalum and Tungsten, followed later by the Gold Supplement. ${ }^{34}$

Article 2 of the Conflict Minerals Regulation, broadly defines 'conflict and high-risk areas'. ${ }^{35}$ The definition includes all areas where there is an armed conflict or which, having had an armed conflict, have not recovered and are fragile. It also refers to areas of political instability, such as locations with governance deficiencies where the political structure and security is precarious or even non-existent. An example provided is that of failed states, in which continuous violations of international law and human rights violations are committed. In this context, reference is also made to the definition of 'armed groups and security forces' mentioned in Annex II of the OECD Conflict Minerals Guidance.

This broad definition creates a certain degree of legal uncertainty, although greater clarity and consistency is provided in Article I/4. Article I 4 calls on the Commission, in consultation with the European External Action Service and the OECD, to establish non-binding guidelines

34 The 'OECD Due Diligence Guidance for Responsible Supply Chains for Minerals from Conflict-Affected or High-Risk Areas' was endorsed by the OECD Investment Committee and the OECD Development Assistance Committee in the Lusaka Declaration of I $_{5}$ December 20 Iо and was subsequently amended on 17 July 2012 to include a reference to the Gold Supplement.

35 This definition has been regarded favourably by legal doctrine: see O. Martin-Ortega, 'Europe...', supra n. 28 at 228 . 
in the form of a handbook for economic operators explaining how to apply the criteria for determining whether an area is a conflict or high-risk area. According to the guidelines provided by this handbook, a non-exhaustive list of conflict or high-risk areas will be provided, to be updated periodically. The industry demanded an exhaustive list of countries affected by the conflict that companies could use to select their suppliers, but the Commission refused to provide a fixed list. As was evident in the process of negotiations on the Conflict Mineral's Regulation, the intention was to avoid the stigmatising effects that a closed list can have on the countries and areas included, and the de facto boycott of certain areas. In fact, the list is not intended to be decisive in delimiting the scope of the Conflict Minerals Regulation, since it does not exempt Union importers sourcing from areas not included in the list ${ }^{6}$ from compliance with their obligations. Hence the importance of the handbook with appropriate guidelines for companies to correctly identify risk areas and comply with their obligations.

Thus, the Conflict Minerals Regulation is flexible in terms of what is considered to be a conflict zone, which needs to be revised and updated, and does not limit its application to a restricted geographical scope; unlike the Dodd-Frank Act, which has a narrower scope and provides a fixed number of pre-established areas, and consequently may fail to meet actual needs. In fact, the type of negative effects that are to be avoided are not only characteristic of the countries identified in the Dodd-Frank Law (Democratic Republic of the Congo and adjoining countries). There are other mineral-producing countries ${ }^{37}$ where extraction difficulties (especially when done by hand), together with political instability in the mining areas and poverty all contribute to an increasing risk of potential human rights violations, given the absence of guarantees to ensure respect of human rights. The dynamic list reduces the possibility of a country being embargoed and is therefore considered a good measure to avoid any unintended consequences that the rule might have.

\section{(3) Timeframe: is the long transitional period too long?}

The Conflict Minerals Regulation was adopted on I7 May 2or7. It was published in the Official Journal of the European Union on 19 May 2017 and, pursuant to Article 2o, it entered into force twenty days after its publication. It was generally applicable from 9 July 2017 , but in reality, most of the provisions that impose effective obligations on importers will be applicable from I January 202I, which will be the definitive implementation date.

This 4-year transitional period seems excessively long. It is intended to make it easier for the economic operators involved to adapt to the new system of due diligence obligations and, above all, it is directed to setting the process in motion. Companies have been encouraged to

$3^{6}$ Measure that 'may be excessively burdensome for importers, who will have to deal with a large volume of bureaucracy and costs that may have a negative impact on their finances when they do not source conflict minerals', as stated by P. Diago Diago, 'El control del...', supra n. 28 , at 2

37 Venezuela, Colombia, Brazil, India, China, Myanmar and Thailand, among others, also have coltan, cobalt and gold mines. 
prepare for the effective fulfilment of their obligations by the implementation date as required. Measures include some preparatory tasks to be performed by the Member States, the Commission and the High Representative of the Union for Foreign Affairs and Security Policy (hereinafter the Commission). This implementation period gives all those affected by the standard (exporting countries, importing countries and companies) some time to prepare for implementation of the standard and to strengthen their due diligence systems. This encourages companies and suppliers to work together to bring their systems into compliance with the standard. The aim is to try to avoid the unintended consequences that the abrupt disruption of trade in conflict areas may have for the countries of origin.

According to Article ro of the Conflict Minerals Regulation, Member States were required to designate the competent authorities responsible for the application of the Regulation and inform the Commission of their names and addresses by 9 September 2or7. The Commission is responsible for publishing this list in the manner set out in Annex III and for keeping it up to date in the light of changes reported by Member States. The list of competent authorities was published - with some delay - on 6 June 2019 (data updated to March $2019^{3^{8}}$ ).

The designated competent authorities are responsible for ensuring the effective and uniform application of the Conflict Minerals Regulation throughout the European Union (Article Io). They are also responsible for carrying out the necessary controls to ensure that the Union's importers comply with the obligations laid down in the Conflict Minerals Regulation and, where appropriate, to establish appropriate sanctions.

The Commission is also to consult with the European External Action Service and the OECD during the transitional period, and to prepare a handbook with guidelines that will help economic operators to identify conflict or high-risk areas. As discussed in the previous section, the purpose of this handbook is to provide an indicative list of major conflict or highrisk areas to allow companies to correctly implement the Conflict Minerals Regulation. Nevertheless, this is not an exclusive list, because Union importers sourcing from areas not mentioned in it will continue to be responsible for the fulfilment of the obligations laid down in the provisions. The handbook has not yet been published. ${ }^{39}$ While it is possible to have an idea of what 'conflict area' means according to the definitions established in the Conflict Minerals Regulation and, therefore, of the companies that will be potentially affected, this delay will reduce companies' operability and their progressive adaptation to the Regulation during the transitional period. Consequently, the Conflict Minerals Regulation to a certain extent, is failing to meet its expectations.

$3^{8}$ This information was taken from the European Commission website, available here, last accessed on 13 October 2020.

39 However, a small Guide was published in March 2017, see 'A quick Guide if you' re involved in the trade in tin, tungsten, tantalum, or gold'. In August 2020 was published a DG Trade Statistical Guide; last accessed on 13 October 2020. 
(4) Personal scope: one of the major weaknesses of the Conflict Minerals Regulation

The Conflict Minerals Regulation requires EU companies in the supply chain to ensure that their imports of the minerals and metals do not come from conflict areas. However, as can be seen from the definition of the mineral supply chain in Article 2, obligations will be imposed on those organisations and actors involved in moving and processing the minerals from the extraction site to their incorporation in the final product. By setting the limit on this incorporation of the mineral into the final product, the definition of supply chain only applies to direct importers of minerals based in the EU. However, it leaves out companies that import already manufactured electronic components and have a key role in the supply of the products and their arrival on the market. Compared to the definition of the supply chain provided in the OECD Conflict Guidance, the Regulation is less ambitious and ignores those companies that are involved in the manufacture and sale of the final product. According to the OECD Conflict Minerals Guidance, the supply chain ends with the sale of the final product and includes those who participate from 'extraction site downstream to its incorporation in the final product for end consumers'. This notably increases the number of operators involved in due diligence tasks and gives greater prominence to the companies that have more visibility for the consumer in the market.

The wording of Article s of the Conflict Minerals Regulation is even stricter in this respect, and exempts part of the companies included in its own definition of supply chain by introducing supply chain due diligence obligations only for those Union importers of minerals or metals whose volume of imports of each of the minerals or metals exceeds the minimum laid down in Annex I.

This is in line with the definition of importers in Article 2 of the Conflict Minerals Resolution. Firstly, it points to any natural or legal person declaring minerals or metals for release for free circulation within the meaning of Article 20 of of Rulation (EU) No. 952/20I3 laying down the Union Customs Code..$^{\circ}$ In so doing, it identifies those who fall within the definition of direct importers based in the EU. And secondly, to direct importers in the EUwho import the established minimum volume. Thus, it further restricts its material scope by means of a second predetermined threshold which leaves out those importers who do not exceed it through a process based on companies' own information on their imports. This is intended to exclude small and medium-sized enterprises, which would not be able to cope with the excessive bureaucratic burden that the introduction of the Regulation's due diligence system may entail. However, it would have been more appropriate to include them,

$4^{\circ}$ Based on Article 20 I of Regulation (EC) 952/20I3 of 9 October 2or3, OJ ro October 2or3: 'Release for free circulation shall entail the following: the collection of anyimport duty due; the collection, as appropriate, of other charges, as provided for under relevant provisions in force relating to the collection of those charges; the application of commercial policy measures and prohibitions and restrictions insofar as they do not have to be applied at an earlier stage; and completion of the other formalities laid down in respect of the import of the goods.' 
but to also give them appropriate means to implement the system during the process.

Article I 8 lays down the methodology for setting these minimum volumes, which are to be published in Annex I on the basis of customs information that shall be provided by the Member States at the request of the Commission on the annual import volumes into their respective territories by Union importer. The Commission will use this information to select the highest annual import volume per Union importer corresponding to no less than $95 \%$ of the total annual volume of imports into the Union. On the date of publication of the Conflict Minerals Regulation, the first thresholds were established by volume and by type of mineral. These were excessively high quantities (especially for some of the minerals) that not only left out a large number of companies that were exempted from the obligations established in the Regulation, but also corresponded to market values that can be a strong incentive to buy arms or promote bribes in the producing countries. 4 $^{1}$

Finally, it should be noted that under the Conflict Minerals Regulation, companies that recycle minerals or stocks that include the above-mentioned minerals sourced before I February 20I3 are also excluded from the obligations provided. However, the Regulation will indirectly affect smelters and refiners insofar as the importers concerned are obliged to ensure that their sources of supply come from responsible smelters and refiners. The Commission's tasks include preparing an overall list of responsible smelters and refiners that comply with the requirements set out in the Conflict Minerals Regulation, as set out in Articles 8 and 9. The Commission will also be required to update the list as the Regulation is gradually implemented and companies strengthen their due diligence process.

Different types of obligations are established for upstream companies, which extract and refine the minerals (mining companies, raw material traders, smelters and refiners) and for downstream companies, which process minerals into finished products and sell them to other businesses, governments or private individuals. While all upstream companies must comply with the due diligence obligations set out in the Regulation, a distinction is made between different types of downstream companies: those that import metal-stage products, which must also comply with due diligence obligations, and those that operate beyond the metalsage, which do not have the same obligations. However, the latter companies are required to use reporting and other tools to help make their due diligence more transparent and promote the due diligence system. ${ }^{4^{2}}$ Through this differentiation, the Regulation emphasises the link in the chain where there is a greater risk, but it may also run the risk of causing manufacturing tasks to be transferred to non-EU countries in order to avoid compliance with the obligations

4I The amount of gold that companies must trade in to fall within the scope of the Regulation was at least Ioo $\mathrm{kg}$. per year. As each gram of gold is priced at around 43 euros, roo kg. of gold will buy a substantial number of weapons.

$4^{2}$ Directive 2014/95/EU of the European Parliament and of the Council of 22 October 20I4 amending Directive $2013 / 34 / \mathrm{EU}$ as regards the disclosure of non-financial information and information on diversity by certain large companies and certain groups, OJ ${ }_{5}$ November 2oI $_{4}, \mathrm{~L}_{33}$ /. 


\section{laid down.}

It can be concluded that the personal scope of application of the Conflict Minerals Regulation is more restrictive than that of the OECD Conflict Minerals Guidance and then that of the Dodd-Frank Act. The latter includes companies that use conflict minerals directly or indirectly through their suppliers in manufactured products, provided that the mineral was 'necessary to its functionality' or 'necessary for the production' of the product. ${ }^{43}$ The Conflict Minerals Regulation exempts from compliance those companies that import the manufactured electronic component, as they are not required to ascertain whether or not the product contains these minerals, or whether their suppliers have applied any due diligence scheme. And, at the same time, it differentiates between those that operate with small quantities and do not reach the minimum thresholds, which would also be exempt from complying with the Regulation's provisions.

Taking all this into account, the European Commission provided an estimate of the number of European companies to which the Conflict Minerals Regulation will apply. Between 6oo

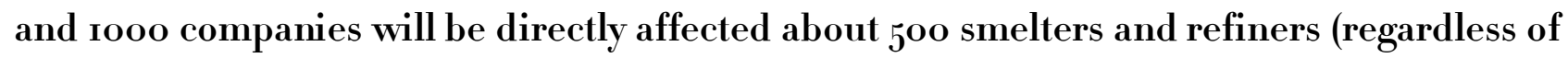
whether or not they have their headquarters in the European Union) will be indirectly affected by the Regulation. ${ }^{4}$

\section{(D) THE EU DUE DILIGENCE SYSTEM}

The Conflict Minerals Regulation establishes a system of due diligence in the supply chain of conflict minerals that is called the Union System. The Union System implements a set of obligations in order to provide greater transparency and legal certainty to the supply practices of the Union's importers, smelters and refiners of conflict minerals that are supplied in the established areas and throughout the chain. The aim is curtailing the opportunities for armed groups and security forces to use the trade in these minerals to finance their illegal activities.

This is a due diligence system based on the OECD Conflict Minerals Guidance to. It consists of four types of obligations that constrain affected importers to identify actual or potential risks and prevent or reduce their negative effects. This differs from the compliance-based approach of American law. The value of trade in minerals in the countries of origin has been emphasised, and in order to minimise the consequences that the rule could have in these territories, the approach to the obligations was modified. Companies were no longer required to label their products as 'conflict free' and were able to work together with suppliers to implement the due diligence system. These obligations include: management system obligations (Article 4); risk management obligations (Article 5); third-party audit obligations (Article 6); and disclosure obligations (Article 7).

43 As established by the Commission on the website that explains how the Regulation works.

44 See more information here. 
It should be noted that the obligations of importers will be accompanied by monitoring and checks by the competent authorities appointed by the States (Article II) that urge companies to comply with recommendations that were merely optional both under the OECD Guide and the Dodd-Frank Act. This involves taking one-step further towards stronger due diligence systems in Europe.

(I) Management system obligations

Article 4 of the Conflict Minerals Regulation refers first of all to the main obligations on importers, and generally defines some basic standards against which supply chain due diligence is to be conducted. To this end, the five steps of the OECD Conflict Minerals Guidance are taken as a starting point and developed further $t$ in certain aspects.

To begin with, EU importers will be obliged to initiate a due diligence policy to identify and assess the potential risks of adverse impacts in their mineral supply chain. This is a risk-based system that in turn depends on whether activities are carried out in the conflict-affected areas stipulated in Annex II. This assessment is an initial obligation for all companies with a potential risk, in order to demonstrate that their activities are consistent with the Control Minerals Regulation. This first obligation may initially have an impact on a larger number of companies. No specific method is established to identify risks and carry out the risk assessment, so it is left to companies to state whether their activities involve a risk or a potential risk with the sole indication that they must comply with the OECD Conflict Minerals Guidance and Annex II, and that they must report the information detailed in Article 4 of the Conflict Minerals Regulation.

However, there is a provision that sets out that these risks shall be assessed on the basis of reports drawn up under Article 6 of the Conflict Minerals Regulation within a third-party audit of smelters and refiners. Based on the recognised reports and due diligence schemes, the Commission shall provide a list of responsible smelters and refiners worldwide that are at least partially sourcing minerals from conflict zones. If those reports are not available and where there are no recognised schemes, companies should manage this information themselves through independent third-party audits. Importers that provide substantive evidence that all smelters and refiners involved in their supply chain comply with the requirements of the Conflict Minerals Regulation shall be exempted from the obligation to carry out third-party audits. In this way, some minimum standards are established whereby companies already operating with due diligence systems are not required to engage in additional paperwork.

To oversee the proper implementation of the responsible supply chain policy, companies should structure their own internal management systems and keep records of this information for at least five years. In cases when the importer is not a natural person, the responsibility for overseeing the process will fall on 'senior managers', (Article 4.c). One more 
step is still needed to hold these managers fully responsible, which would involve introducing possible sanctions when the competent authorities find problems in the implementation of the due diligence policy. As already mentioned, the decision to introduce a system of ad hoc sanctions will be taken by each Member State (Art. i6).

In addition, in order to introduce due diligence standards throughout the supply chain, the Conflict Minerals Regulation provides that responsible policy goes beyond mere informing suppliers and therefore due diligence standards should be incorporated into contracts and agreements with them. This world effectively extends obligations to other actors that do not fall within the material scope of the Conflict Minerals Regulation but will be indirectly affected by its due diligence mechanisms.

An important new development of the Conflict Minerals Regulation is that, unlike the Dodd-Frank Act, it incorporates the obligation to include or encourage a grievance mechanism, which includes an early-warning risk-assessment system, which it will promote through collaboration agreements with suppliers or other economic operators or organisations (Article 4.c).

In establishing the characteristics of the supply chain policy, the Regulation provides some indication as to the obligations to be met by importers depending on whether they are importers of minerals, metals or by-products. These obligations are intended to 'operate a chain of custody or supply chain traceability system that provides (...) information' on minerals and metals. This information includes the basic characteristics of the mineral or metal and of the importer, including its trade name, type, name and address of the EU importer. In addition, the country of origin and quantities must be given in the case of minerals and data from refiners or smelters in the supply chain of the EU importer must be provided in the case of metals. For minerals or metals originating from conflict or high-risk areas for which potential risks have been identified, data should be provided on the mines of origin or locations where the affected resources are consolidated, traded and processed, as well as the taxes, fees and royalties paid. In this way, very useful information is available that will allow complementary traceability and certification measures to be established in parallel with the implementation of the basic obligations for importers. It is necessary to have this information, which is to be found in the initial stages of the chain, because once the product has been processed it is almost impossible to identify its origin. 45

In the case of metals, the records of third-party reports or audits (or evidence of compliance, as mentioned above) shall be provided. If these reports are not available, the data on the countries of origin of the minerals in the supply chain of smelters and refiners or additional information shall be provided in accordance with the specific recommendations for

45 Ashighlighted byP. Diago Diago, 'El control del comercio...', supra n. 28, at 3, and P. Diago Diago, 'Minerales y diamantes en conflicto: mecanismos de control y diligencia debida en tiempos ODS”, 63 Deusto Journal of European Studies (2020) ${ }_{153}^{-182}$. 
downstream companies provided by the OECD Conflict Minerals Guidance.

As far as importers of by-products are concerned, documentation supporting the information on the origin of these by-products must be provided, that is, the point where the by-product has been separated for the first time from its primary mineral or metal.

(2) Risk management obligations

Once the due diligence policy structure has been described, Article 5 of the Conflict Minerals Regulations sets out the obligations for importers to identify and manage any potential risks. The aim is to establish a risk management strategy consistent with Annex II of the Conflict Minerals Regulation, which will lead them to adopt measures aimed at reducing or mitigating them, or even at preventing the negative effects that these risks could have.

The risk management strategy of the Conflict Minerals Regulation again makes a distinction between the obligations for importers of minerals and for importers of metals. Importers of minerals, havingidentified and assessed risks through the information gathered in the previous article, must implement a strategy to deal with those risks. This process begins by reporting findings to those responsible for the risk management structure (senior management), so that they can exert pressure on the suppliers who can most effectively prevent or mitigate the identified risk. These measures are linked to the business relationship between the importer and the supplier and can range from continuing trade with those suppliers while simultaneously implementing measurable risk mitigation efforts to temporarily suspending trade while pursuing those efforts; to di sengaging from the supplier after several failed attempts to reduce risks. The risk reduction model is based on Annex III of the OECD Conflict Minerals Guidance: 'Suggested Measures for Risk Mitigation and Indicators for Measuring Improvement'. It suggests a series of steps to mitigate risks and provides indicators for assessment (Article $5 \cdot 3$ of the Conflict Minerals Regulation).

This step involves shifting the point in time when action is taken. The obligations of importers are intended to verify or evaluate the efforts that their suppliers are making or have made. In order to assess risk reduction efforts, under the Conflict Minerals Regulation importers are invited to consult local authorities or central governments, international organisations and/or civil society organisations and affected third parties on the state of play. In this way, EU importers' pressure will sometimes have an impact on operators that do not fall within the scope of the Regulation, extending the Regulation's scope of influence but making it easier to work together with suppliers. And strong emphasis is made in the Conflict Minerals Regulation on involving those who can report on the effects that non-responsible practices can have on the place of origin. Their fieldwork can play a major role, as they can apply complementary measures of traceability, certification and information..$^{6}$

$4^{6}$ There are several regional and international traceability initiatives: Certified trading chains (German Geological survey in collaboration with the DRC, Rwanda, Burundi); Conflict-free gold standard (world gold 
The risk assessment to be carried out by metal importers under the Mineral Regulation will be different. Based on Article 5.4 of the Conflict Minerals Regulation, they will be required to assess supply chain risks on the basis of available third-party audit reports on smelters and refiners. Their evaluation of the due diligence processes shall be in accordance with Annex II of the OECD Conflict Minerals Guidance: 'Model Supply Chain Policy.' Once risks have been identified and information has been reported to senior management, the strategy to reduce or avoid adverse effects must be consistent with the provisions in Annex II, which is also aimed at incorporating a responsible sourcing policy into contracts and agreements with suppliers. Given the place of metals in the supply chain, measures on metals make even greater emphasis on collaborating with authorities and organisations in the producing country, which results in the focus being placed on the early stages of the supply chain.

\section{(3) Third-party audit obligations}

Article 6 of the Conflict Minerals Resolution concerns the obligations of EU importers of minerals and metals to carry out audits through independent third parties. This is one of the major differences between the Regulation and the Dodd-Frank Act. While the Dodd-FrankAct originally included a similar obligation, it was immediately repealed. ${ }^{47}$ Third-party audits play a key role in the Conflict Minerals Regulation, as they evaluate all the activities and processes used by importers. The audits shall determine the conformity between the practices adopted by importers and the Regulation's due diligence system, and provide appropriate recommendations for improvement. In addition, audit reports will serve as a basis for evaluating the risk management of metal importers when taking measures for mitigation, reduction or elimination. In general, the conditions for audits follow the guidelines of the OECD Conflict Minerals Guidance, and should be consistent with the principles of independence, competence and accountability.

The obligations of the audits are aimed at verifying that importers meet their obligations. Therefore, those importers who have demonstrated through reliable evidence (including third party audit reports) that all smelters and refiners in their supply chain comply with the standards of the Regulation will be exempted. In fact, those importers of metals who source only from smelters and refiners included in the list of responsible smelters and refiners to be drawn up by the Commission pursuant to Article 9 of the Conflict Minerals Regulation (published as Annex II) will not be required to provide evidence. A model based on the traceability and certification of smelters and refiners is indirectly promoted, although some

\footnotetext{
council); conflict-free smelter programme(EICC, GeSI); Conflict-free Tin initiative (Dutch government), ICGLR regional certification mechanism; responsible gold guidance (London bullion market association), see J. Masika,'Mujeres y minería artesanal: el impacto de los sistemas de trazabilidad en las comunidades de Rubaya/Masisi en la República Democrática del Congo’, in G. Otano and P. Aleman (eds), Synergie des femmes (Bilbao September 2oI7).

47 M. C. Márquez Carrasco, and I. Vivas Teson, (coord.). 'La implementación...', supra n. 24, at 3.
} 
additional work remains to be done on the certification of mines in situ..$^{8}$

(4) Disclosure obligations

Article 7 of the Conflict Minerals Resolution deals with the disclosure obligations of metal and mineral importers. Firstly, the reports drawn up by third party audits or, where appropriate, substantial evidence of compliance with the diligence schemes recognised by the Commission under Article 8 must be disclosed and made available to the competent authorities chosen by the Member States (Article ro).

Article 7 also establishes an obligation to make information on the supply chain available to their immediate downstream purchasers. This is the only obligation in which the Conflict Minerals Regulation expressly refers to downstream operators who make the final product available to the customer and who, as seen in the personal scope of the Regulation, are exempted under the established definition of what a supply chain is. However, Article 7. 2 stipulates that disclosure will be made 'with due regard for business confidentiality and other competitive concerns.' This addresses a concern that companies have but makes it significantly more unlikely for the information to reach the end consumer. It also reduces the transparency of the scheme, which is one of the key objectives of the Conflict Minerals Regulation.

Article 7.3 serves to reinforce this point and reiterates the obligation for importers of either metals or minerals to publicly report on their due diligence policies and responsible sourcing practices 'as widely as possible'. This information is also to be published on the Internet and includes the measures they have taken to comply with the obligations relating to their management system (in accordance with Article 4) and their risk management (in accordance with Article 5) of the Conflict Minerals Regulation. ${ }^{49}$

(5) Alternative due diligence schemes

The Conflict Minerals Regulation also provides for the possibility of recognising due diligence schemes which are already in operation and are similar to those laid down in its Articles. As provided for in Article 8, governments, industry associations and groupings of interested organisations having due diligence schemes in place may apply to the Commission to have the

$4^{8}$ The Conflict Minerals Regulation must have some accompanying measures at the place of production to ensure improved conditions for workers in mines. In order for the change in supply and supply policies to be truly effective, accompanying measures must be insisted upon, as highlighted in a report by The European Networkfor CentralAfrica (EurAc) 'Accompanying Measures in the EU Regulation on the responsible sourcing of minerals', March 20I7. The European Parliament attempted to introduce a provision (Article I5 a) in the Proposal for a Regulation) by means of amendment 55 , in which it called for the Commission to establish a Programme of accompanying measures in order to ensure the effectiveness of the Union System, but it ultimately did not succeed, P8_TA (2015) 0204.

49 T. Bradshaw, ‘Apple to name-and-shame suppliers of conflict of minerals', Financial Times, I3 February 2014 . 
supply chain due diligence schemes that are developed by them recognised by the Commission. This would avoid an unnecessary increase of bureaucracy to ensure the functioning of the Union System. The Commission, following an evaluation process (designed through the delegated regulation established in the Delegated Regulation (EU) 20I9/429 of II January $2019^{5^{\circ}}$ ) will issue a recognition of equivalence with the requirements of the System laid down in the Conflict Minerals Regulation on the basis of the information and evidence provided by the companies. In doing so, it shall specifically take into account the risk-based approach and method for the purpose of identifying conflict areas. If a scheme applies for recognition and fails to meet the requirements, remedial action will need to be taken to overcome the deficiencies. In this way, the Conflict Minerals Regulation becomes the promoter of a uniform due diligence standard in the minerals field at European level.

Finally, in order to make the public aware of these programmes, the Commission will establish a register of those schemes that have been recognised as being equivalent to the Union System, which will be made publicly available on the Internet. This register will be regularly updated with the information provided by the companies.

\section{(E) FINAL REMARKS}

The Conflict Minerals Regulation establishes the first common due diligence system applicable for all European States. It involves standards in responsible sourcing policy not previously seen in any other field: the European System. It is a true milestone and marks the beginning of a positive trend in respect for human rights and in the social responsibility of companies in the extraction of minerals from conflict areas, which undoubtedly deserves to be applauded. The Conflict Minerals Regulation should be taken as a starting point on a path of no return towards respect for human rights by European companies. Although it could have been more ambitious, it is an example of the slow but gradual progress that is now being made towards the definitive implementation of due diligence across Europe.

However, this could have been an opportunity to move forward further in this direction, particularly bearing in mind that some stricter measures were proposed in the initial negotiation rounds and through the European Parliament's amendments which failed to be incorporated into the final text. Their removal or lack of approval ultimately weakened the Resolution's effectiveness.

One of the major weaknesses of the Conflict Minerals Regulation is the limited scope of its material application; for example, even though demand for cobalt is increasing and will further grow in the coming years with the introduction of electric vehicles, this mineral is not included in the scope of the Resolution. Even though it followed in the footsteps of the Dodd Frank Act and the OECD Conflict Minerals Guidance in this regard, its material scope could

5o 
have been determined in a more generic manner that would enable its expansion according to the needs of the minerals and/or metals trade.

Similarly, the personal scope is considered excessively restrictive, in that it only includes direct importers of minerals and leaves out companies that import electronic devices or manufactured components. In addition, when determining the importers concerned, the Resolution establishes a scale based on volume thresholds to delimit its personal scope, which leaves out those undertakings which do not exceed those volumes. The problem is that the volumes thresholds were too high, which significantly reduces the number of companies affected; the operations conducted by some companies may therefore continue to encourage armed groups and contribute to perpetuate the conflict. In determining the quantity, no account has been taken of the cost of these minerals on the market and their hypothetical value for buying arms or financing the conflict.

One of the most successful aspects of the Conflict Minerals Regulation is the absence of limitations as regards the determination of the conflict area, which marks the scope of the Regulation's application, as well as its potential geographical scope of influence. The absence of a closed list will help to determine its scope in line with the changing needs of society worldwide and to avoid any unintended consequences on the countries of origin.

It can be concluded that the Regulation is a crucial step in the right direction for ensuring the implementation of a strong due diligence scheme. This is a system that requires EU companies to guarantee compliance with certain minimum standards as regards the protection of human rights when they carry out international activities in different States; and to require those involved in their supply chain to do so as well. However, it is still a system based on voluntary compliance with these obligations, the duty of which lies with legal operators. Thus, an opportunity has been missed to establish specific sanctions for non-compliance with the obligations established by the Union System. It will be necessary to wait for its definitive implementation and for the development by States of ad hoc legislation, as provided for in

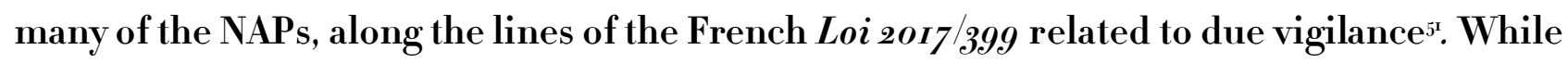
this Law could also have taken further steps forward, for the first time it requires companies to comply with due diligence obligations, and it provides that they may be held responsible in the event of non-compliance.

${ }^{5}$ Loi n 20I7-399 du 27 mars 2017 relative au devoir de vigilance des sociétés mères et des entreprises donneuses d'ordre, JORF n. oo74 du 28 mars 2017. 